УДК 783.3

\title{
Е. Литвиненко \\ ДУХОВНЫЕ ОСНОВЫ ХОРОВОЙ ШКОЛЫ К. К. ПИГРОВА И ТРАДИЦИИ «ПРАВОСЛАВНОЙ КАНТАТЫ» В ТВОРЧЕСТВЕ С. И. ТАНЕЕВА
}

Статья посвящена рассмотрению духовных основ хоровой школь К. К. Пигрова, органично соединившего в своей методике светскую и церковную традиции хорового пения, что в совокупности способствовало развитию не только профессиональных дирижерских и вокальнопевческих навыков музыканта, но и его духовного мира. Составной частью «школы К. К. Пигрова» можно также считать ее репертуарную специфику, в рамках которой существенное место принадлежит музыке С. И. Танеева, в частности феномену «православной кантаты».

Ключевые слова: хоровая школа К. К. Пигрова, кантата, «православная кантата», творчество С. И. Танеева.

Г. Струве, размышляя о сущности хора и хорового искусства, однажды заметил следующее: «Хор - это прообраз идеального общества, основанного на едином устремлении и слаженном дыхании, общества, в котором важно услышать другого, прислушаться друг к другу» [12]. В данном высказывании известный хормейстер сосредоточил свое внимание не только на специфике технико-исполнительской стороны хорового искусства как такового, но также и на его духовной составляющей, становящейся залогом формирования гармоничного человеческого сообщества как единого соборного целого. Обозначенный подход характеризует и деятельность одесской хоровой школы, базис которой составили принципы работы с хором, сформулированные К. К. Пигровым. Органично соединив в своей методике светскую и церковную традиции хорового пения, К. К. Пигров тем самым обозначил «полипараметровость исполнительского хорового стиля - множественность его уровней и свойств» [13, c. 160], составляющую в совокупности предмет неиссякаемого исследовательского интереса. Сказанное определяет актуальность темы представленной статьи, предмет которой ориентирован на обобщение духовных основ хоровой школы К. К. Пигрова в соотнесенности с ее репертуарной спецификой, в частности с поэтикой «православной кантаты» в творчестве С. И. Танеева, неизменно входившей в репертуар не только «пигровского хора», но и хоровых коллективов его последователей.

(C) Литвиненко Е., 2016 
Обозначенный подход «школы К. К. Пигрова», ориентированный на «авторский синтез» двух хоровых исполнительских традиций, соединивший «академическую церковность» и светский хоровой стиль, достаточно закономерен и во многом обусловлен не только значимой ролью хорового пения в мировой музыкальной культуре, но и этимологией самого слова «хор», пришедшего из греческого языка. На профанном уровне в различные исторические эпохи под ним подразумевалась и «хороводная пляска с пением», и «коллективный участник древнегреческих трагедий и комедий», и, наконец, «коллектив певцов, которые совместно исполняют какоелибо вокальное произведение с инструментальным сопровождением или без него» [3, с. 39].

Одновременно этимология слова «хор» и производных от него слов указывает и на его сакральные признаки. В этом случае слово «хор», соотносится и с «хоро» («коло») и родственным ему словом «хоровод» и некоторыми другими, сопряжен в своем значении с понятием «круга» как одного из важнейших символов божественного, сакрального начала, актуального как для славян-язычников (бог Хорс - воплощение Солнца), так и для христиан. В последнем случае имеется в виду «хорос» - круглое паникадило в церкви как одна из важнейших составляющих восточнохристианского храмового комплекса, сопряженного с символикой Бога-Света. По мнению А. Ю. Годованец, исследующей особенности данного феномена в византийской культуре, «Св. София уподобляется образу огромной неугасимой лампады, византийскому паникадилу-хоросу, говоря словами Прокопия, «на цепи подвешенному к небесам». Так храм становился образом мира и, одновременно, образом души» [2, с. 47], устремленной к внутреннему преображению как главной цели жизни христианина.

Подобного рода значимая духовная роль принадлежит и хору как одному из важнейших участников христианской богослужебной практики, начиная с раннего Средневековья, поскольку его деятельность считается непосредственно сопряженной с концепцией «ангелогласия», которое, по словам В. В. Медушевского, есть выражение «проработанного духом звукового материала» (цит. по: [4, с. 66]). Именно хор и хоровое пение (на уровне богослужебно-певческого искусства) на протяжении многих столетий олицетворяли высочайшую духовную миссию музыки в европейской культурно-исторической традиции, сохранявшую значимость не только в период Средневековья, но и в последующие эпохи. 
Связующим звеном в определении духовной сущности музыки от раннего Средневековья вплоть до современности выступает определение А. Ф. Лосева, убежденного в том, что «музыка, снимая пространственно-временной план бытия и сознания, вскрывает новые планы, где восстанавливается нарушенная и скованная полнота времен и переживаний и открывается существенное и конкретное всеединство или путь к нему». Осознавая великую преобразующую силу музыки, исследователь соотносит способность «музыкально жить» с потенциальной возможностью для человека «управлять вселенной, имманентно присутствуя в каждой монаде стремящихся струй бытия. Музыкально жить и чувствовать - значит превратить бытие в звучащий и бесконечный инструмент вечности» [5, с. 263, 267].

Таким образом, богослужебное хоровое пение, возникшее на базе Небесного первообраза, олицетворяло собой молитву-аскезу, «поющее богословие», воспитание «богоприимного ума» (св. Дионисий Ареопагит), путь духовного восхождения человека. Это искусство воплощение «полноты мира в своем проявлении. Музыкальный порядок (совокупность метра, ритма, мелодии, гармонии) есть отражение вселенского порядка, внутри которого - своеобразно и соподчиненно ему - осуществляется бытие культуры». Отметим при этом, что именно «тоновый звук есть начало культуры» [1].

Осознание высокой духовной миссии хорового искусства, сохраняющееся вплоть до нынешнего времени, показательно и для всей педагогическо-исполнительской деятельности К. К. Пигрова, вся жизнь которого, по словам А. П. Серебри, характеризовалась «непреодолимым влечением к хоровому пению» (цит. по: [13, с. 63]). Этапы творческой биографии этого выдающегося музыканта, достаточно подробно представленные в его очерке [10], в исследовании И. Шатовой «Стилевые основы одесской хоровой школы» [13], а также в воспоминаниях его современников и учеников-последователей (см. [9]), свидетельствуют о его приобщенности к высокой хоровой традиции, начиная с детского возраста. Здесь весьма существенна и практика пения в церковном хоре, начиная с 6-7 лет, и занятия в духовном училище, духовной семинарии и, наконец, в регентском классе Петербургской певческой капеллы, которая на протяжении нескольких столетий была оплотом высочайшего профессионализма в сфере хорового искусства. Будучи долгое время, в противовес Синодальном хору Москвы, олицетворением синтеза отечественной и западноевропейской певческих традиций, унаследованных в концертном сти- 
ле Д. Бортнянского, капелла, тем не менее, давала хорошую профессиональную базу своим ученикам, воспитывая на основе церковных песнопений и ярких образцов композиторского творчества в данной области музыкальность, идеальный слух, вокально-певческие навыки и прекрасные человеческие души.

Вооруженный подобным солидным «багажом», в котором сочеталось знание и западноевропейской музыкальной культуры, и отечественной богослужебно-певческой традиции во всем разнообразии ее проявлений, К. К. Пигров наиболее полно реализует свой методический, педагогический и дирижерско-исполнительский потенциал именно в Одессе. «Особенностью одесской культуры (в широком понимании) всегда являлась ее «европейскость». Одессу строили европейские мастера, приезжали европейские музыканты, и, естественно, такое тесное сотрудничество с западноевропейскими странами повлияло и на церковно-певческую культуру» [13, с. 70].

Совмещая на протяжении достаточно длительного периода работу регента в кафедральном соборе с руководством хорового факультета Одесской консерватории, К. К. Пигров, как свидетельствуют многие его современники, в совершенстве владел как концертным аффектированным, так и молитвенно строгим, сдержанным стилями интерпретации весьма широкого и стилистически разнообразного хорового репертуара.

Тем не менее, при работе с любым сочинением для К. К. Пигрова определяющими факторами его методики неизменно оставались чистота интонации, воспитание «культурного звука» при развитии подвижности и гибкости голоса, скрупулезная работа над дикцией, а также над развитием художественного вкуса певцов на материале высоких образцов певческого хорового искусства. Необходимо отметить, что все обозначенные положения «школы К. К. Пигрова» генетически восходят опять-таки к церковно-певческой традиции «ангелогласного пения» с показательной для нее «культурой звука», «чистотой строя» и особым отношением к Слову как носителю Божественной истины и средству духовно-нравственного очищения и совершенствования человека.

Итог реализации принципов обозначенной методики Мастера предполагал не только развитие профессиональных певческих и дирижерских навыков, но прежде всего воспитание и преображение души, соприкасаюшейся с высоким мастерством. По воспоминаниям В. Н. Луговенко относительно интерпретации моцартовского Рек- 
виема, «исполнительская концепция К. К. Пигрова, в развитии тенденций содержательности духовных жанров, привносила в звучание в изобилии ту Радость Гармонии, которая облекала катарсическим Преодолением самые горестные мрачно-трагические образы» [9, с. 149]. Обобщая стилевые основы одесской хоровой школы и роль в ней К. К. Пигрова, И. А. Шатова отмечает, что «церковную практику исполнять богослужебную музыку ради Духовного Совершенствования исполняющих К. К. Пигров перенес на светскую хоровую практику и научно обосновал свои методико-педагогические принципы воспитания хормейстера в труде «Руководство хором». Он стремился духовные традиции богослужебного хорового искусства перенести в стены светского заведения» [13, с. 160], что стало особенно очевидным после его вынужденного прекращения регентской деятельности и полного сосредоточения на работе в консерватории.

Выделенные аспекты «школы К. К. Пигрова», в которой, как видим, одинаково значимыми были как воспитание профессиональных навыков, так и их духовное осмысление, проявлялись и в выборе репертуара консерваторского хора, в котором неизменно доминировали либо лучшие образцы отечественного фольклора и его обработки, либо шедевры хоровой классики (И. С. Бах, В. А. Моцарт, Й. Гайдн, Г. Ф. Гендель, Дж. Верди, Н. Леонтович, Л. Ревуцкий, Г. Свиридов и др.).

Особое место в перечне сочинений, над которыми постоянно работал К. К. Пигров, занимает музыка С. И. Танеева. Известно, что в 1953 году к 100-летнему юбилею композитора хор Одесской консерватории подготовил тематический концерт из сочинений данного автора. В числе прочих в его программу вошли такие произведения, как «Развалины башни», «На могиле», «Увидал из-за тучи утес», «Вечер», «Посмотри, какая мгла» и др. Однако особый интерес К. К. Пигров проявлял к кантатам С. И. Танеева. В своей методической работе он часто ссылался на музыкально-интонационную специфику кантаты «По прочтении псалма». Кантата «Иоанн Дамаскин» и поныне входит в репертуар консерваторского хора, будучи объектом изучения и проработки многочисленных поколений студентов-хормейстеров. Одновременно, по воспоминаниям учеников К. К. Пигрова, данная кантата была, вероятно, одним из созвучных его духовному состоянию произведений. По воспоминаниям А. П. Серебри, «в последние годы жизни он, хоть и чувствовал себя хорошо, все же перед летними каникулами на занятии хора, говоря о планах на следующий год, 
расстраивался и просил хор спеть «Иду в неведомый мне путь»... из «Иоанна Дамаскина» [10, с. 4]. Подобное эмоционально и духовно прочувствованное понимание музыки С. И. Танеева свидетельствует, на наш взгляд, о родственности натур и таланта этих двух выдающихся деятелей отечественной культуры, для которых служение Музыке и осознание ее высочайшей духовной миссии в жизни человека составляло смысл их жизни и профессиональной деятельности.

С. И. Танеев - одна из наиболее ярких творческих фигур русской музыки рубежа XIX-XX ст., известныХ не только своим пристрастием к традициям полифонического искусства, но и стремлением к поиску путей консолидации отечественной и западноевропейской музыкально-исторической традиции, что, собственно, и послужило основанием для возникновения жанра «православной кантаты», представленной названными выше сочинениями.

Время творческой деятельности С. И. Танеева приходится на рубежный, переломный период истории русской культуры и музыкального искусства, именуемый обычно как «русский духовный (религиозный) ренессанс». В профессиональном музыкальном творчестве этого времени взаимодействовали две наиболее значимые тенденции. Первая из них была связана с возрождением древнейших традиций православного церковно-певческого обихода и сопряженной с ним идеи соборности, «всеединства», коллективного сознания, в то время как вторая тенденция отражала усиливающуюся значимость личностного психологического начала. В конечном итоге философия «духовного ренессанса» акцентировала внимание на космологии и антропологии, получивших в рамках русской христианской философии и культуры этого периода новую жизнь.

Русская музыка рубежа XIX-XX столетий также испытывала повышенный интерес к категориям надвременного и трансцендентного, будучи устремленной к постижению макрокосмоса - Бога и Человека, поскольку «не внешняя действительность определяет человеческую жизнь, а внутренняя духовная жизнь и интенсивная душевная работа человека и общества. Микрокосмос человека становится макрокосмосом» [8, с. 20]. Соответственно, философско-религиозные идеалы вселенскости, добра, любви, красоты, милосердия, самопожертвования, воплощенные в разнообразных музыкальных формах, жанровых типологиях и стилях, определяли ценностное содержание творчества русских композиторов и исполнителей указанного периода. 
В свете сказанного особую значимость приобретают, наряду с оперой и инструментальной музыкой, хоровые жанры, в частности кантата, поскольку именно они более всего ассоциировались в религиозно-философских концепциях современников русских музыкантов рубежа столетий с соборно-вселенским началом. Аналогичная значимость характеризует и хоровое исполнительское искусство, достигшее в этот период высокого расцвета. Сказанное подтверждается, например, позицией К. С. Аксакова, отождествлявшего соборность с общиной, в которой «личность свободна как хорист в хоре» (цит. по: [8, с. 11]). Откликаясь на духовные запросы своего времени, каждый из русских композиторов, тем не менее, интерпретировал их по-своему, что и нашло запечатление в концепции «православной кантаты» в наследии С. И. Танеева.

Многообразие характеристик авторского стиля С. И. Танеева «неоклассицист» (Н. А. Римский-Корсаков), «чистый романтик с громадным темпераментом» (Н. Я. Мясковский), «запоздалый нидерландец» (В. Г. Каратыгин), «русский Бах» (И. Ф. Бэлза), представитель «классицистского романтизма» (Т. Н. Левая) - отражает преломление в танеевском мышлении характерного для русской культуры XIX века поиска путей к русско-европейскому синтезу. Н. А. Римский-Корсаков в «Летописи моей музыкальной жизни» пишет: «Танеев 80-х годов был человек резко консервативных убеждений в музыкальном искусстве. Честный, прямолинейный, Танеев говорил резко, прямо и откровенно. В 90-х годах, сохранив свою поразительную контрапунктическую технику, он отдался творчеству более свободно и руководствовался идеалами современной музыки» [11, с. 272]. Этот отзыв известнейшего русского композитора свидетельствует о постепенном формировании в среде музыкантов и критиков конца XIX ст. убеждения в том, что С. И. Танеев - не только композитор «академического толка», но и художник, остро чувствующий настроение эпохи и выражающий свои замыслы современным языком.

В связи с вышесказанным весьма закономерным является интерес композитора к жанру кантаты, хотя его творчество представлено также и иными сферами - симфониями, оперой «Орестея», камерно-вокальными произведениями и др. Огромный интерес к кантате и высокие творческие «выходы» в названной области во многом обусловлены, на наш взгляд, тем фактором, что именно данный жанр послужил для С. И. Танеева средоточием как его творческо-научных устремлений, так и духовно-этических. Именно жанр кантаты по- 
зволял композитору найти точки соприкосновения между русской музыкально-исторической традицией, которую он представлял, и западноевропейской, в которой также был весьма осведомлен. Одновременно типология хоровой кантаты достаточно хорошо «вписывалась» и в контекст жанровых и духовно-стилевых исканий русской культуры рубежа XIX-XX столетий, обобщенных в понятии «религиозный ренессанс».

Сказанное обусловливает новаторский подход С. И. Танеева к жанру кантаты, в рамках которого композитор стремится к поискам путей синтезирования отечественной и зарубежной духовно-хоровой традиции. Из первой, то есть из отечественной, он черпает интонационный язык, в том числе и традиции русского духовного мелоса. От западной традиции он заимствует обширное многовековое наследие полифонического искусства. Результатом становится появление в истории русской музыки нового типа кантаты, апеллирующего как к традициям православного духовно-хорового пения, так и к наработкам западноевропейского многоголосия различных эпох.

Обобщение подобного рода приводит С. И. Танеева к определению данного жанра на уровне «православной кантаты», сформулированному композитором следующим образом: «Мне хочется взять в основание... кантаты, древние мелодии нашей церкви и таким образом написать православную кантату, подобно тому, как существуют протестантские кантаты, основанные на протестантских хоралах» (цит. по: [6, с. 208]). Именно с кантатным жанром композитор связывал возможность в обобщенной форме выразить сущностные черты современного (для эпохи композитора) понимания Человека и духовного мира.

Итак, кантаты «Иоанн Дамаскин» и «По прочтении псалма» возникли на пересечении отечественной духовно-певческой и западноевропейской вокально-полифонической традиции, представленной наследием ренессансной полифонии и духовно-хоровой музыкой барокко (И. С. Бах, Г. Ф. Гендель). Названные истоки одинаково сущностно важны для стиля С. И. Танеева и его концепции «православной кантаты». С протестантской кантатой (к которой апеллирует композитор) его сочинения связывает не только цитирование песнопений богослужебно-певческого обихода («Иоанн Дамаскин»), обогащенное барочной музыкально-риторической традицией, а также завоеваниями полифонической техники (которой С. И. Танеев овладел в совершенстве), но и использование в качестве словесной ос- 
новы поэтического «пересказа» духовных текстов (Стихиры Иоанна Дамаскина, 49 псалом), определяющих проповеднический характер данных сочинений.

Вместе с тем, кантаты С. И. Танеева имеют принципиальные отличия от своих протестантских аналогов, что проявляется в очевидном обращении именно к отечественной духовно-певческой традиции, обогащенной идеями «русского духовного ренессанса», в соотнесенности «Иоанна Дамаскина» с традициями духовного концерта, в очевидном доминировании хорового «соборного» начала в обеих кантатах. Отметим также, что, если баховская кантата как «проповедническая музыка» выступает частью богослужения, то аналогичные композиции С. И. Танеева бытуют как концертные хоровые сочинения, тем не менее выполняющие функцию «сакрализации» светской музыкальной традиции. В «Иоанне Дамаскине» она реализуется через апеллирование к теме смерти и типологии реквиема-панихиды, в то время как кантата «По прочтении псалма» олицетворяет собой масштабное воплощение «антропо-космической концепции» понимания композитором сущности Бытия и высокого духовного Призвания Человека, реализуемой через опору на лучшие традиции отечественного богослужебно-певческого и профессионального хорового искусства.

Подводя итог приведенному выше обзору духовных оснований «школы К. К. Пигрова» и роли в ней поэтики «православной кантаты» С. И. Танеева, необходимо отметить, что, принадлежа к различным поколениям отечественной интеллигенции начала XX столетия, оба музыканта руководствовались в своей деятельности критериями не только высочайшего профессионализма, знания своего «дела жизни», но и его духовными основаниями. И К. К. Пигров, и С. И. Танеев на осознанном либо неосознанном уровне так или иначе стремились к творческому осуществлению идеи всеединства, которая пронизывала всю русскую культуру рубежа XIX-XX ст. Для С. И. Танеева она реализовалась на уровне органического синтеза Духа отечественной певческой традиции и достижений западной полифонии, обобщенных в поэтике «православной кантаты». Для К. К. Пигрова - это опыт создания универсальной методики хорового воспитания, в рамках которой духовно-певческая и регентская традиция православной культуры выступала фактическим базисом светской хоровой исполнительской традиции, будучи преобразованной в направлении «интерпретирующей художественности» [13, с. 161]. 
Так, в сущности, смыкаются творческие задачи двух великих музыкантов прошлого, чье искусство и поныне составляет ярчайшую страницу хоровой музыки и исполнительства, поскольку жизненный путь каждого из них можно было бы определить словами Г. Свиридова: «Музыка как забава. Музыка как профессия. Музыка как искусство. Музыка как судьба» (цит. по: [7]).

\section{СПИСОК ЛИТЕРАТУРЫ}

1. Апрелева В. Музыка как фундаментальное выражение культуры и предвосхищение особенностей ее развития [Электронный ресурс]: дис. ... доктора философских наук : 09.00.04 - Эстетика / В. А. Апрелева. - М., 1999. - Режим доступа : www.dissercat.com/content/

2. Годованец А. «Ночное солнце». Реконструкция устройства искусственного освещения храма Св. Софии Костантинопольской / А. Ю. Годованец // Декоративное искусство и предметно-пространственная среда. Вестник МГХПА. - М. : МГХПА им. С. Г. Строганова, 2009. - № 1-1. - С. 36-49.

3. Коляда Е. Хор / Е. И. Коляда // Музыкальная энциклопедия: в 6 томах / [гл. ред. Ю. В. Келдыш]. - М. : Советская энциклопедия, 1982. - Т. 6 : Хейнце - Ягушин. - С. 39-40.

4. Комков О. О некоторых аспектах феноменологии восточнохристианского художественного текста / О. А. Комков // Вестник Московского университета. Серия 19 : Лингвистика и межкультурная коммуникация. 2009. - № 4. - С. 58-73.

5. Лосев А. Из ранних произведений / А. Ф. Лосев. - М. : Правда, 1990. $655 \mathrm{c}$.

6. Лукина Г. Идеи и интонационный строй музыки С. И. Танеева : дис. ... доктора искусствоведения : 17.00.02 - Музыкальное искусство / Г. У. Лукина. - М. : МГК им. П. И. Чайковского, 2014. -408 с.

7. Масленникова Н. Георгий Свиридов : «Музыка несет Душу Мира». На столетие Георгия Васильевича Свиридова (1915-1998) [Электронный ресурс] / Н. Масленникова. - Режим доступа : www.mgarsky-monastery.org/kolokol/

8. Ноздрина А. Философские идеи в русском музыкальном творчестве XIX - начала XX веков : автореф. дис. ... канд. философских наук : 09.00.13 - Религиоведение, философская антропология, философия культуры / А. П. Ноздрина. - Ростов-на-Дону: Северо-Кавказский научный центр высшей школы, 2004. - 26 с.

9. Одесская консерватория. Славные имена, новые страницы / [ред. кол. Н. Л. Огренич, Е. Н. Маркова (ред.-сост.) и др.]. - Одесса : ООО «ГрандОдесса», 1998. - $336 \mathrm{c}$.

10. Пигров К. Хоровая культура и мое участие в ней / К. К. Пигров // Сборник статей / [ред.-сост. А. П. Серебри]. - Одесса : Одесская государственная консерватория им. А. В. Неждановой, 2001. - 50 с. 
11. Римский-Корсаков Н. Летопись моей музыкальной жизни / Н. А. Римский-Корсаков. - М. : Музыка, 1989. - 447 с.

12. Цитаты о музыке и музыкантах [Электронный ресурс]. - Режим доступа : zagorskaya.vsv.lokos.net/biblioteka/972

13. Шатова И. Стилевые основы одесской хоровой школы : монография / И. Шатова. - Одесса : Астропринт, 2013. - 184 с.

Литвиненко О. Духовні основи хорової иколи К. К. Пігрова та традицї̈ «православної кантати» в твориості С. I. Танєєва. Стаття присвячена розгляду духовних основ хорової школи К. К. Пігрова, що органічно поєднала у своїй методиці світську та церковну традиції хорового співу та сукупно сприяла розвитку не тільки професійних диригентських та вокально-співочих навичок музиканта, але і його духовного світу. Складовою частиною «школи К. К. Пігрова» можна також вважати ії репертуарну специфіку, в межах якої суттєве місце належить музиці С. І. Танєєва, зокрема феномену «православної кантати».

Ключові слова: хорова школа К. К. Пігрова, кантата, «православна кантата», творчість С. І. Танєєва.

Litvinenko E. Spiritual foundation K. K. Pigrov and traditions «orthodox cantata» choir school in the works of Sergei Taneyev. The article is devoted to the spiritual foundations of the school choir K. K. Pigrov organically connected at its methodology secular and ecclesiastical tradition of choral singing, which together contributed to the development not only of conducting professional and vocal and choral skills of the musician, but also his spiritual world. An integral part of «K. K. Pigrov schools» can also be considered the specifics of its repertoire, in which an important place belongs to the music of Sergei Taneyev, in particular, the phenomenon of «orthodox cantata».

Keywords: school choir K. K. Pigrov, cantata, «orthodox cantata», creativity Sergei Taneyev.

Стаття надійщла до редакції 13.04.2016

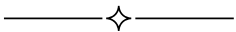

